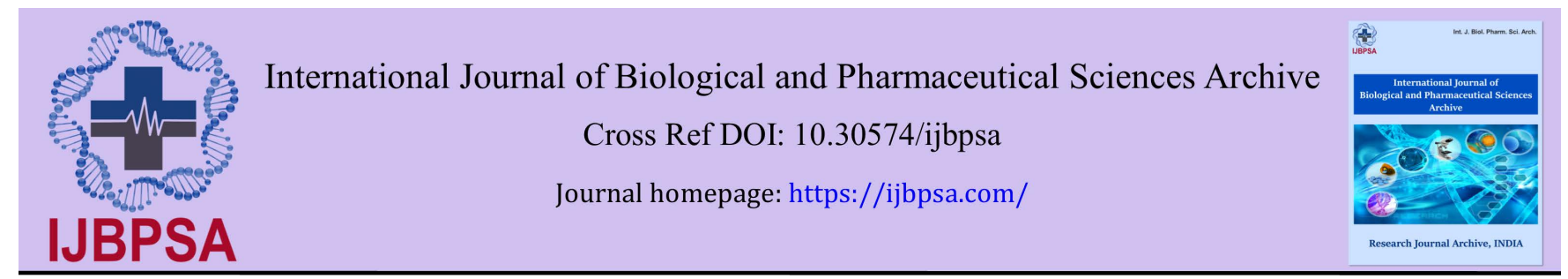

(RESEARCH ARTICLE)

\title{
Heavy metals assay of herbal pharmaceutical effluent
}

\author{
Aziz Ur Rahman ${ }^{1, *}$, Muhammad Owais ${ }^{2}$ and Irfan Ansari ${ }^{2}$ \\ ${ }_{1}$ Department of Chemistry, Government Degree Boys College, 5-L, New Karachi, Karachi, Pakistan. \\ ${ }^{2}$ Department of Energy and Environment, Hamdard University, Karachi, Pakistan..
}

International Journal of Biological and Pharmaceutical Sciences Archive, 2021, 01(02), 161-166

Publication history: Received on 08 April 2021; revised on 19 May 2021; accepted on 23 May 2021

Article DOI: https://doi.org/10.30574/ijbpsa.2021.1.2.0037

\begin{abstract}
Environmental pollution particularly from heavy metals in effluent is the gravest problem in developing countries like Pakistan. Effluents of Herbal Pharmaceutical are waste water generated during Herbal Medicines manufacturing process. When these effluents deprived of appropriate treatment are released directly into the environment, results in potential adverse effects on human health and the environment. This research work examined the heavy metals parameters of effluents discharged by Herbal pharmaceutical industry in Karachi, Pakistan. In all, 08 parameters were studied. These include $\mathrm{Cr}, \mathrm{Mn}, \mathrm{Fe}, \mathrm{Co}, \mathrm{Ni}, \mathrm{Cu}, \mathrm{Ag}$ and $\mathrm{Pb}$. The study revealed that ranges of $\mathrm{Ag}$ and Fe were exceeding the allowable limit of WHO (World Health Organization) and NEQS (National Environmental Quality Standards). This calls for an immediate use of latest treatment plants to decrease the harmfulness that results from waste water.
\end{abstract}

Keywords: Herbal medicines; Wastewater; Heavy metals pollution; Toxicity

\section{Introduction}

Herbal drugs is growing rapidly and their use as organic medicine all over the world specially in developing countries because of its effectiveness, safety, traditional acceptability, reasonable cost and low side effects related to allopathic medicines [1, 2, 3, 4]. World Health Organization (WHO) is reported that herbal medicines are profitable worldwide and they represent a market worth of approximately US\$ 43 billion per year. Nearly $80 \%$ population of the world use herbal drugs mainly in the developing countries.

Because of difference in the kinds of medicines generated, raw materials used and founded upon market demands Herbal pharmaceutical industries produce a huge volume of extremely biodegradable effluent. It is reported by WHO [5] that a significant proportion of people use medicinal plant remedies and the figure is on the increase as population increase particularly in younger generation in both developed and developing countries $[6,7,8]$. It is reviewed that there are 10 renowned regulatory industries producing herbal pharmaceutical goods merely that are circulated in all the sectors of the country.

Various kinds of pollutants are present in the effluent produced during the manufacturing process of herbal medicines $[9,10,11]$. This effluent is a complex constituent of heavy metal ions, alkaloids, toxic solutes and plant extracts that participate to environmental pollution [12,13,14]. The nature of pollutant in effluent is in soluble and insoluble [15]. The waste water release into drainages and then move into water bodies making widespread pollution and frightening to the aquatic life and health of nearby human population [16]. The present study is undertaking with the objective to examine the presence of heavy metals: $\mathrm{Cr}, \mathrm{Mn}, \mathrm{Fe}, \mathrm{Co}, \mathrm{Ni}, \mathrm{Cu}, \mathrm{Ag}$ and $\mathrm{Pb}$ in herbal pharmaceutical industry effluent and their possible impacts if any.

\footnotetext{
* Corresponding author: Aziz Ur Rahman

Department of Chemistry, Government Degree Boys College, 5-L, New Karachi, Karachi, Pakistan.

Copyright (@ 2021 Author(s) retain the copyright of this article. This article is published under the terms of the Creative Commons Attribution Liscense 4.0.
} 


\section{Material and methods}

\subsection{Sampling}

This research work was carried out in Karachi. Pakistan. The selected Herbal Pharmaceutical industry discharges its effluent without treatment because there is no operational wastewater treatment capability within its vicinity. Effluents are released at every phase of production including run off water into exposed drainage. Total 08 representative samples are collected in three different sampling points. The parameters determined were: $\mathrm{Cr}, \mathrm{Mn}, \mathrm{Fe}, \mathrm{Co}, \mathrm{Ni}, \mathrm{Cu}, \mathrm{Ag}$ and $\mathrm{Pb}$.

\subsection{Analytical Procedures}

The chemicals were of analytical grade and according to the specification of manufacturer's, all the instruments were calibrated and tested. The collection of samples, handling and analysis were conducted according to the standards [17]. Duplicate analyses of the samples were run. Appearance, odor and color of the herbal industry wastewater were measured in the field itself. $\mathrm{Cr}, \mathrm{Mn}, \mathrm{Fe}, \mathrm{Co}, \mathrm{Ni}, \mathrm{Cu}, \mathrm{Ag}$ and $\mathrm{Pb}$ were measured by using Atomic Absorption Spectrophotometry (AAS). Data obtained from the analyses were run using SPSS- 20.

Table 1 Heavy metals concentration in Effluent

\begin{tabular}{|c|c|c|c|c|c|c|}
\hline \multirow[b]{2}{*}{ S.NO } & \multirow[b]{2}{*}{ Metals } & \multicolumn{4}{|c|}{ Concentration (ppm) } & \multirow{2}{*}{$\begin{array}{r}\text { NEQS/ } \\
\text { WHO }\end{array}$} \\
\hline & & Effluent-A & Effluent-B & Effluent-C & $\begin{array}{l}\text { Composite } \\
\text { Effluent-D }\end{array}$ & \\
\hline 1 & Co & 0.01 & 0.015 & 0.019 & 0.015 & \\
\hline 2 & $\mathrm{Cr}$ & 0.01 & 0.013 & 0.018 & 0.014 & $1.0 \mathrm{ppm}$ \\
\hline 3 & $\mathrm{Ni}$ & 0.01 & 0.012 & 0.016 & 0.013 & $1.0 \mathrm{ppm}$ \\
\hline 4 & $\mathrm{~Pb}$ & 0.01 & 0.011 & 0.014 & 0.012 & $0.5 \mathrm{ppm}$ \\
\hline 5 & $\mathrm{Ag}$ & 3.85 & 3.89 & 3.99 & 3.91 & $1.0 \mathrm{ppm}$ \\
\hline 6 & $\mathrm{Fe}$ & 3.4 & 3.46 & 3.47 & 3.44 & $2.0 \mathrm{ppm}$ \\
\hline 7 & $\mathrm{Cu}$ & 0.02 & 0.024 & 0.026 & 0.023 & $1.0 \mathrm{ppm}$ \\
\hline 8 & $\mathrm{Mn}$ & 0.11 & 0.116 & $0 . .118$ & 0.115 & $1.5 \mathrm{ppm}$ \\
\hline
\end{tabular}

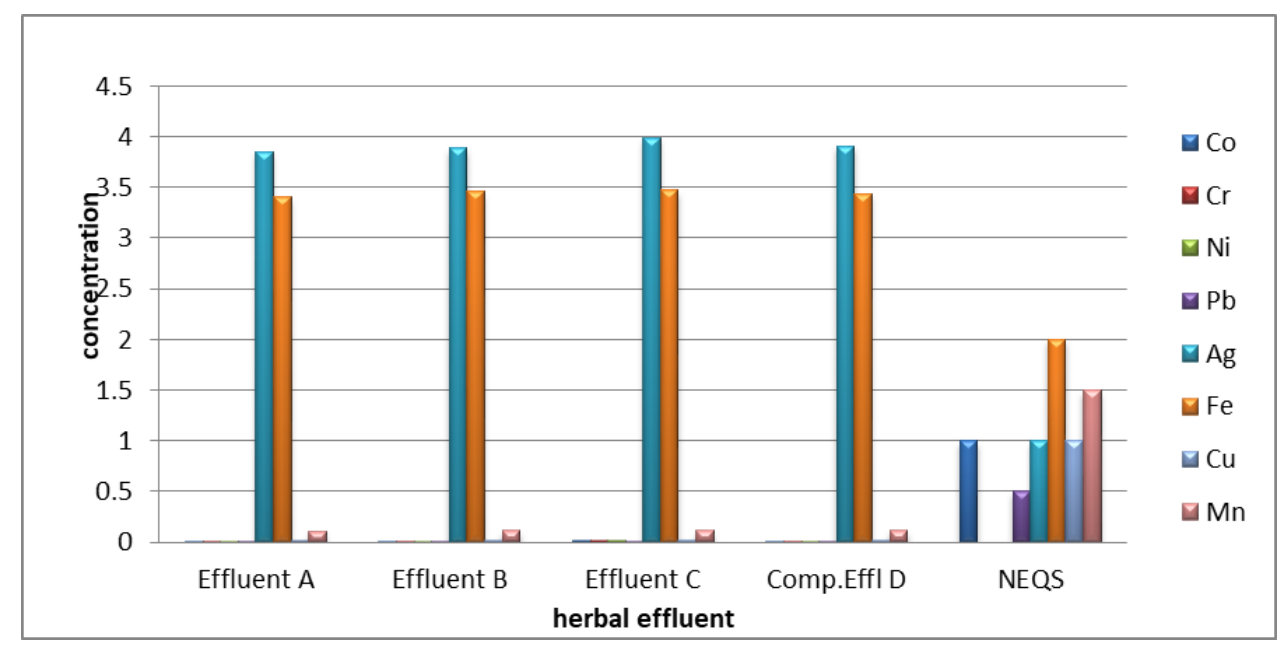

Figure 1 Heavy metal ions concentration 


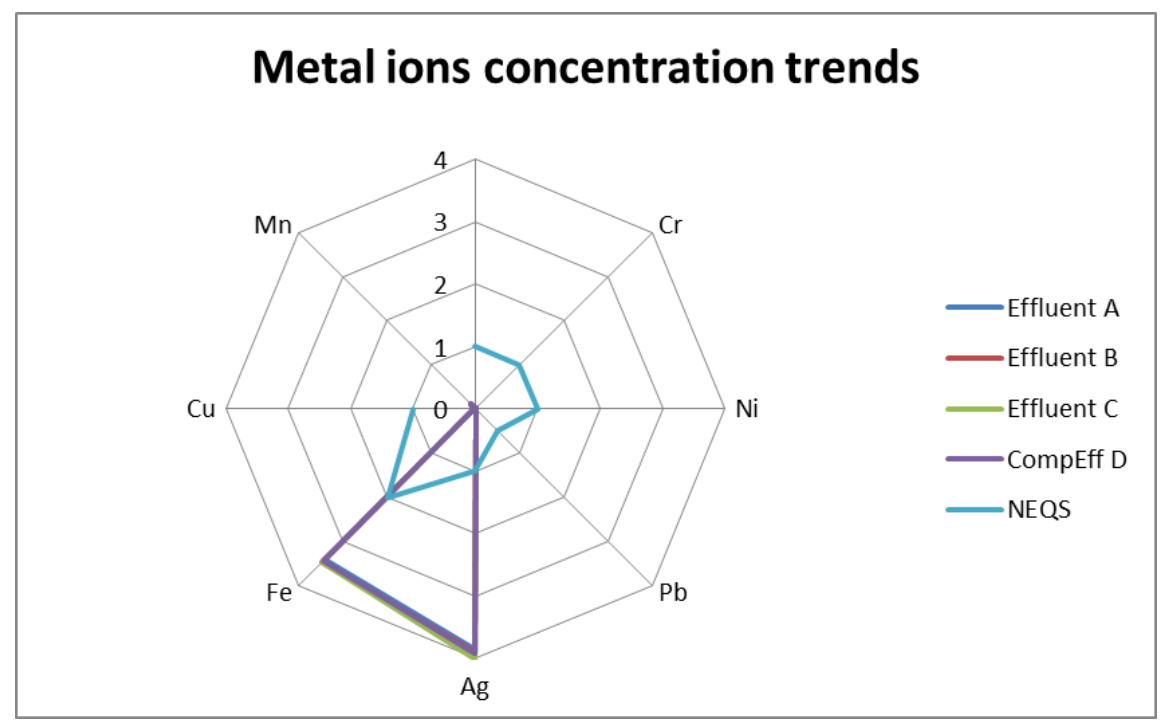

Figure 2 Heavy Metal ions concentration trends

Table 2 Descriptive statistics of heavy metal ions

\begin{tabular}{|c|c|c|c|c|c|c|}
\hline \multirow{2}{*}{ Metals } & N & Minimum & Maximum & \multicolumn{2}{|c|}{ Mean } & Std. Deviation \\
\cline { 2 - 7 } & Statistic & Statistic & Statistic & Statistic & Std. Error & Statistic \\
\hline $\mathrm{Co}$ & 4 & 0.010 & 0.019 & 0.01475 & 0.001843 & 0.003686 \\
\hline $\mathrm{Cr}$ & 4 & 0.010 & 0.018 & 0.01375 & 0.001652 & 0.003304 \\
\hline $\mathrm{Ni}$ & 4 & 0.010 & 0.016 & 0.01275 & 0.001250 & 0.002500 \\
\hline $\mathrm{Pb}$ & 4 & 0.010 & 0.014 & 0.01175 & 0.000854 & 0.001708 \\
\hline $\mathrm{Ag}$ & 4 & 3.850 & 3.990 & 3.91000 & 0.029439 & 0.058878 \\
\hline $\mathrm{Fe}$ & 4 & 3.400 & 3.470 & 3.44250 & 0.015478 & 0.030957 \\
\hline $\mathrm{Cu}$ & 4 & 0.020 & 0.026 & 0.02325 & 0.001250 & 0.002500 \\
\hline $\mathrm{Mn}$ & 4 & 0.110 & 0.118 & 0.11475 & 0.001702 & 0.003403 \\
\hline Valid N(list wise) & 4 & & & & & \\
\hline
\end{tabular}

Table 3 Correlation analysis

\begin{tabular}{|l|l|l|l|l|l|l|l|l|}
\hline & Co & Cr & Ni & Pb & Ag & Fe & Cu & Mn \\
\hline Co & 1 & & & & & & & \\
\hline $\mathrm{Cr}$ & $0.979^{*}$ & 1 & & & & & & \\
\hline $\mathrm{Ni}$ & $0.968^{*}$ & $0.999^{* *}$ & 1 & & & & & \\
\hline $\mathrm{Pb}$ & 0.940 & $0.989^{*}$ & $0.995^{* *}$ & 1 & & & & \\
\hline $\mathrm{Ag}$ & $0.952^{*}$ & $0.994^{* *}$ & $0.996^{* *}$ & $0.994^{* *}$ & 1 & & & \\
\hline $\mathrm{Fe}$ & 0.942 & 0.855 & 0.829 & 0.772 & 0.805 & 1 & & \\
\hline $\mathrm{Cu}$ & $0.986^{*}$ & 0.938 & 0.920 & 0.878 & 0.906 & $0.980^{*}$ & 1 & \\
\hline $\mathrm{Mn}$ & $0.977^{*}$ & 0.912 & 0.891 & 0.846 & 0.865 & $0.989^{*}$ & $0.989^{*}$ & 1 \\
\hline
\end{tabular}




\section{Results and discussion}

\subsection{Herbal effluent characteristics}

Table 2 showed the descriptive statistic of heavy metals values. The data was compared with the permissible limit of NEQS and WHO and showed in Table 1 and Figure 1 . In the current research study period, the Co ranges was 0.010 ppm to $0.019 \mathrm{ppm}$ and mean value was $0.014 \mathrm{ppm}$ with standard deviation 0.003 ; Cr ranges was $0.010 \mathrm{ppm}$ to $0.018 \mathrm{ppm}$ and mean value was $0.013 \mathrm{ppm}$ with standard deviation 0.003 ; Ni ranges was $0.010 \mathrm{ppm}$ to 0.016 ppm and mean value was $0.012 \mathrm{ppm}$ with standard deviation 0.002 ; Pb ranges was $0.010 \mathrm{ppm}$ to $0.014 \mathrm{ppm}$ and mean value was $0.011 \mathrm{ppm}$ with standard deviation 0.001; Ag ranges was $3.8 \mathrm{ppm}$ to $3.9 \mathrm{ppm}$ and mean value was 3.91 ppm with standard deviation 0.058; Fe ranges was $3.40 \mathrm{ppm}$ to $3.47 \mathrm{ppm}$ and mean value was $3.44 \mathrm{ppm}$ with standard deviation 0.03 ; $\mathrm{Cu}$ ranges was $0.02 \mathrm{ppm}$ to $0.026 \mathrm{ppm}$ and mean value was $0.02 \mathrm{ppm}$ with standard deviation 0.002 and Mn ranges was 0.110 to 0.118 and mean value was $0.114 \mathrm{ppm}$ with standard deviation 0.003 . A thorough study of tables and graphs reveals that the heavy metals Fe and Ag values were significant and exceeding the permissible limit Figure 2 in the samples of herbal industry. This exceed values of heavy metals parameters cause several harmful effect [18]. An alteration in the comparative composition and profusion of the organisms in the water body brings about a corresponding alteration in the heavy metal aspect. Heavy metal parameters considers as ecological variables because high ecological status resemble completely to the values for the heavy metal quality elements must remain within the ranges generally related with uninterrupted conditions[19].

\subsection{Correlation Analysis}

In correlation, four parts of information are significant; the sign of the correlation coefficient, the arithmetic value of the correlation coefficient, the effect size of the correlation and the statistical importance of the correlation. The Pearson correlation of eight parameters of heavy metals is shown in Table 3.

All heavy metals showed very strong positive correlation among themselves. Cr-Ni $(r=0.999), \mathrm{Cr}-\mathrm{Pb}(\mathrm{r}=0.989), \mathrm{Cr}-$ $\mathrm{Ag}(\mathrm{r}=0.994), \mathrm{Cr}-\mathrm{Fe}(\mathrm{r}=0.855), \mathrm{Cr}-\mathrm{Cu}(\mathrm{r}=0.938)$ and $\mathrm{Cr}-\mathrm{Mn}(\mathrm{r}=0.912)$; Fe-Cu $(\mathrm{r}=0.980), \mathrm{Fe}-\mathrm{Mn}(\mathrm{r}=0.989)$; Co-Cr ( $r=0.979)$, Co-Ni ( $r=0.968)$, Co-Ni $(r=0.968)$, Co-Pb ( $r=0.940), \mathrm{C} 0-\mathrm{Ag}(r=0.952)$, Co-Fe $(r=0.942)$, C0-Cu ( $r=0.986)$ and Co-Mn $(r=0.977)$; Ni-Pb $(r=0.995)$, Ni-Ag $(r=0.996)$, Ni-Fe $(r=0.829), \mathrm{Ni}-\mathrm{Cu}(r=0.938)$ and Ni$\mathrm{Mn}(\mathrm{r}=0.891)$; Cu- Mn(r= 0.989); Ag- Fe ( $\mathrm{r}=0.805)$, Ag- Cu (r=0.906) and Ag-Mn (r=0.865); Pb- Ag (r = 0.994) , Pb$\mathrm{Fe}(\mathrm{r}=0.772), \mathrm{Pb}-\mathrm{Cu}(\mathrm{r}=0.878)$ and $\mathrm{Pb}-\mathrm{Mn}(\mathrm{r}=0.846)$. High correlation of heavy metals parameters indicates same source

\section{Conclusion}

The present investigation on heavy metals of Herbal pharmaceutical industry effluent shows high concentration of Ag and Fe as compared to permissible limit of NEQS and WHO. The upshot of untreated wastewater from herbal pharmaceutical industry has accrued over years causing into pollution of water bodies around the effluent's drainage and in the sub-soil.

Correlation analysis indicates moderate to strong correlation among heavy metals. The strong positive correlation is a sign of same source. The exposed parameters are governed by the similar anthropogenic source

The current research work reveals that the constituents of herbal pharmaceutical wastewater are heavy metals that are released into the environment. They are hazardous in nature and can deteriorate the environment. Following measures should be taken to overcome this issue:

- The raw materials of different sorts that are used in herbal pharmaceutical industry should either modify or substitute with other non-hazardous materials.

- The source of hazardous materials and manufacturing design should be amended by engaging different sorts of scientific techniques.

- Zero liquid waste discharged concepts should be adopted.

- Rules, regulation and norms of Herbal pharmaceutical industries should be strict. 


\section{Compliance with ethical standards}

\section{Acknowledgments}

The authors desire to appreciate the Laboratory facilities provided by Dr. Arshad Mehmood of Archroma Pakistan Limited.

\section{Disclosure of conflict of interest}

Authors declare no conflict of interest.

\section{References}

[1] Susan S. Importance and effectiveness of herbal medicines. Journal of Pharmacognosy and Phytochemistry. 2019; 8(2): 354-357.

[2] Tapsell LC, Hemphill I, Cobiac L et al. Health benefits of herbs and spices: the past, the present, the future. Med. J. Aust. 2006; 185(4): S4-24.

[3] Calixto JB. Efficacy, safety, quality control, marketing and regulatory guidelines for herbal medicines (phytotherapeutic agents). Braz. J. Med. Biol. Res. 33 (2): 179-189.

[4] Inamdar N, Edalat S, Kotwal VB and Pawar S. Herbal drugs in milieu of modern drugs. Int. J. Green Pharm. 2008; 2(1): 2-8.

[5] World Health Organization, WHO. Guidelines for Assessing Quality of Herbal Medicines with Reference to Contaminants and Residues, World Health Organization, Geneva, Switzerland. 2006.

[6] Nandy T, Kaul SN, Szpyrcowicz L. Treatment of herbal pharmaceutical wastewater with energy recovery. International Journal of Environmental Studies. 1954; 83-105.

[7] Vanerkar A, Shanta S, Dharmadhikari DM. Full Scale Treatment of Herbal Pharmaceutical Industry Wastewater. International Journal of Chemical and Physical Sciences. 2013; 2 (special issue):52-62.

[8] Jain G, Satyanarayan S, Navghare P, Kaul SN, Szpyrkowicz L. Treatment of pharmaceutical wastewater (Herbal) by a coagulation/flocculation process. Intern. J. of Environ. Studies. 201; 58: 313-330.

[9] Ziarati P. Determination of contaminants in some Iranian popular herbal medicines. Journal of Environmental \& Analytical Toxicology. 2001; 2(1): 1-3.

[10] Li SM, Fang Y et al. Heavy metals in Chinese therapeutic foods and herbs. Journal of the Chemical Society of Pakistan. 2012; 34(5): 1091-1095.

[11] Alwakeel SS. Microbial and heavy metals contamination of herbal medicines. Research Journal of Microbiology. 2008; 3(12): 683-691.

[12] Saeed M, Muhammad N, Khan H. Assessment of heavy metal content of branded Pakistani herbal products. Tropical Journal of Pharmaceutical Research. 2011; 10(4): 499-506.

[13] Sitre S, Dhadse S, Satyanarayan S. Toxicity of herbal pharmaceutical wastewater to a freshwater crustacean Ceriodaphnia dubia. Bull. Environ. Contam. Toxicol. 2009; 82: 275-279.

[14] Vanerkar AP, Satyanarayan S, Dharmadhikari DM. Toxicity of herbal pharmaceutical wastewater on fish Lebister reticulatuus (Peters). J Environ Sci Health B. 2004; 39(1):115-123.

[15] Savita D, Deepa D. Analysis of Effluent Using Physico-Chemical Parameters at Pharmaceutical Industries. CIBTech Journal of Pharmaceutical Sciences. 2013; 1(2-3): 24-27.

[16] Singare PU, Dhabarde SS. Studies on Pollution due to Discharge of Effluent from Pharmaceutical Industries of Dombivali Industrial Belt of Mumbai, India. International Letters of Chemistry, Physics and Astronomy. 2014; 3: 16-23.

[17] APHA. Standard Methods for Examination of Water and Waste Water. American Public Health Association, Washington. Greenberg, A. E., Clescert, L. S., and Eaton Eds, A. D. 18th ed. 1998.

[18] Ernst E. Toxic heavy metals and undeclared drugs in Asian herbal medicines. Trends in Pharmacological Sciences. 2002; 23(3): 136-139. 
International Journal of Biological and Pharmaceutical Sciences Archive, 2021, 01(02), 161-166

[19] Rahman A and Sabir MI. Ecological Risk Assessment of Ground Water Quality of Two Industrial Zones of Karachi, Pakistan. British Journal of Applied Sciences and Technology.2016; 14(2): 1-8. 